\title{
Eco-development aspect in modernization of industrial system
}

\author{
Michat Turski ${ }^{1, *}$ \\ ${ }^{1}$ Faculty of Infrastructure and Environment, Czestochowa University of Technology, 60A Brzeznicka \\ St., 42-200 Czestochowa, Poland
}

\begin{abstract}
In financing mechanism of National Fund for Environmental Protection and Water Management it is necessary to achieve energy savings of at least $20 \%$. However, not always achieving such energy savings means an increase in economic and ecological efficiency. Therefore, the article presents possibilities of investment leading to energy savings, reducing consumption of primary energy contained in the fuel by increasing production efficiency and reducing energy losses directly in the source. This solution will allow to keep economic and ecological savings. Proposed solutions are crucial for the implementation of investment. The improvements proposed in the article, if they have not been implemented so far, should give significant effects in all cases. The study was conducted for the medium-sized Polish company. The company can be considered as representative of food processing industry. The study was conducted on basis of energy efficiency auditing. Based on the obtained results it can be stated that the use of cogeneration, heat recovery and alternative methods of cooling at an appropriate balancing may allow the average annual primary energy saving of 563 toe/year and the reduction in $\mathrm{CO}_{2}$ emissions by $2,413 \mathrm{t}$ /year. Thus achieved energy efficiency index may reach approx. $20 \%$, eco-efficiency index may reach approx. $40 \%$ and economic efficiency index may reach approx. $30 \%$.
\end{abstract}

\section{Introduction}

According to the requirements for enterprises by Law on Energy Efficiency (UEE) of 20 May 2016 the energy efficiency audit (EEAu) of company is mandatory for all large enterprises (from annual average of 250 employees, and from EUR 50 million of annual net turnover, or from EUR 43 million of the total assets of balance sheet). The lack of implementation of EEAu may be saddled with a financial penalty. Enterprises had to perform the audit to 30 September 2017 and must repeat it every 4 years. EEAu should be based on current and measured data. EEAu should concern the following areas of energy management: electricity, heat, gas, cooling, lighting, buildings, transportation, compressed air, renewable energy, industrial installations. It is necessary to include a minimum of $90 \%$ of energy consumption in the company. Auditors must have the necessary competence and experience according to PN-EN 16247 [1].

\footnotetext{
* Corresponding author: m.turski@is.pcz.pl
} 
This material is devoted to the issues of implementation of improvements to heat, gas and cold.

\section{Improvements}

\subsection{Cogeneration}

Cogeneration creates a potential for saving primary energy, which is in the European Union largely untapped [1]. In addition, Law on Energy Efficiency requires the 'efficient district heating and cooling system', which means that the production of heat or cold should be: $50 \%$ of energy from renewable sources, or at least $50 \%$ of energy from waste heat, or at least $75 \%$ of heat from CHP, or at least $50 \%$ of energy from a combination of these sources.

Moreover, arguments for combined production of electricity and heat in dispersed sources of energy are the same as for large power plants: competitiveness, ease of installation-ready solutions, guarantee of continuity of supply by the possibility of using different types of fuel, ecology-reduction of pollutant emissions [2-4]. Cogeneration sources supported by heat storage $[5,6]$ can be a potential to increase the efficiency of the entire heating system.

\subsection{Heat recovery}

In the combustion process fuel is combusted with the participation of an oxygen from air, which is provided by fans. In the combustion chamber exhaust gases, passing through the exchanger, return most of their heat to steam or water. But part of that heat leaves boiler along with exhaust gases. Minimizing chimney losses can save fuel. This can be achieved using two methods (which are considered in the following order), first - regulation of burners and setting the air-fuel ratio to the minimum amount of air in order to minimize the quantity of exhaust gas, second - heat recovery from exhaust gases [7, 8].

\subsection{Free-cooling}

For the purpose of cooling it is convenient to take advantage of low external temperatures. This applies rooms with constant and high internal heat gains, that have to be cooled no matter what weather conditions are on the outside. Examples include server rooms and electronic spaces. For facilities where ventilation must be limited or can't be regulated is good practice to use a free-cooling solution. Energy transporting medium is a mixture of water and glycol. To ensure continuous heat removal, system of free-cooling is connected to conventional refrigeration systems.

The use of low-outside air temperature can be done in two ways: direct and indirect. The process of free-cooling, which takes place in the central air-conditioning system and should multiply the share of outside air is called a direct free-cooling. If the process of air cooling is realized through the use of a refrigerating water which temperature is lowered in the external aggregate we can talk about indirect free-cooling [9-11].

\subsection{Sorption cooling}

Devices such as absorption chillers use thermal energy to production of cold. This solution allows the production of chilled water using waste heat.

Coefficient of Performance (COP) of absorption chillers is in the range of $0.8-1.6$ [9-13]. Taking into account the investment costs, the maximum economic results 
are achieved using absorption chillers in systems with large capacities. Absorption chillers can be supplied with thermal energy, which comes from sources such as waste heat, heat from district heating network, heat from cogeneration module, heat from gas or biomass combustion, heat from solar collectors.

\section{Analysis}

\subsection{Study object}

Analysis concerned heat sources such as: steam gas boiler, water gas boiler and lowparameters water gas boiler. The first boiler was a gas-pressure steam boiler with three-pass construction and with heating power of $490 \mathrm{~kW}$. Boiler efficiency depending on the operating pressure can reach up to $91 \%$. It is possible to raise the efficiency to $95 \%$ by installing the exhaust gas economizer. The steam capacity was between $0,5-3,8 \mathrm{t} / \mathrm{h}$. The second boiler was a hot water gas boiler, to work with a constant water temperature with three-pass boiler construction and with heating power of $490 \mathrm{~kW}$. Boiler efficiency at heating system temperatures $75 / 60^{\circ} \mathrm{C}$ was $95 \%$. The third boiler was low temperature water boiler. Heating power of that boiler was $900 \mathrm{~kW}$. Boiler efficiency was $94 \%$. In the case of the first boiler there was not consider a replacement due to the need to supply steam for technological purposes.

Moreover, analysis concerned of sources of cooling in the form of two compressor chillers, air-cooled, with scroll compressors and plate-evaporators. Cooling power of compressors was $2 \times 102 \mathrm{~kW}$.

To consider the energy savings were illustrated main energy flows associated with the production of steam, hot water, heating and cooling. Also there were established the boundaries of individual areas, in order to measure the effectiveness in constant conditions.

Figure 1 shows a simplified diagram of the main flow of energy supplied to the boiler and expended from the boiler.

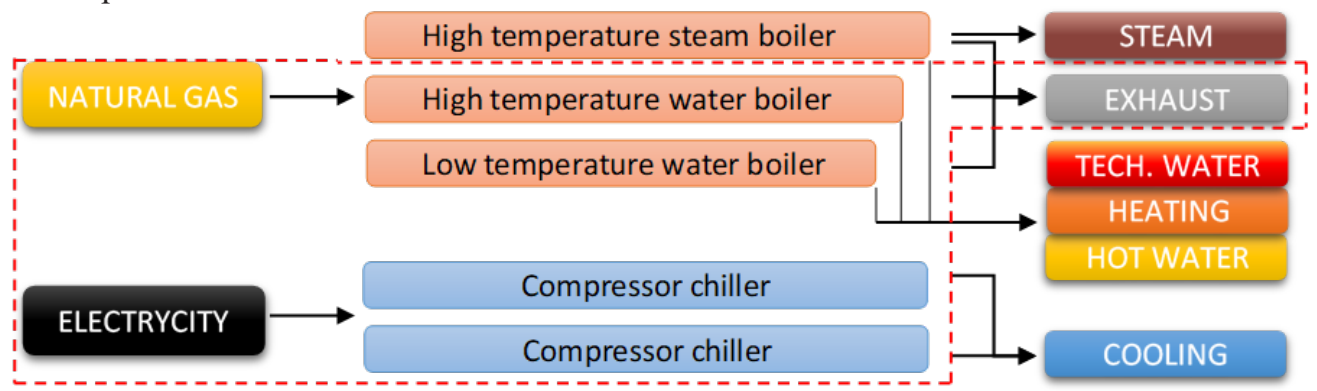

Fig. 1. The main flows of energy supplied to the boiler and expended from the boiler and selection of boundaries for energy balance.

\subsection{Methodology}

The selection of modernization has been made with regard to the possible implementation of improvements. For each of improvements or the group of possible improvements an energy, economic and environmental effects were specified.

Then the ranking of analyzed improvements was made in order of fulfilment of defined criteria.

As criteria for the ranking of improvements for determining possible variants of modernization were chosen criteria that have not assumed only the financial effect. When 
deciding on the scope of modernization were also taken into account aspects such as raising the energy efficiency by $20 \%$.

Based on the previously described possibilities of modernization have been chosen variants, summarized in Table 1.

Table 1. Variants of improvements based on the assessment of the technical condition.

\begin{tabular}{|c|c|c|}
\hline No & Objective & The variants of realization \\
\hline 1. & $\begin{array}{c}\text { Reducing the demand for primary energy } \\
\text { in the fuel }\end{array}$ & $\begin{array}{c}\text { Use of cogeneration instead of high temperature } \\
\text { water boiler }\end{array}$ \\
\hline 2. & $\begin{array}{c}\text { Reducing the demand for primary energy } \\
\text { in the fuel }\end{array}$ & $\begin{array}{c}\text { Use of cogeneration instead of low temperature } \\
\text { water boiler }\end{array}$ \\
\hline 3. & $\begin{array}{c}\text { Heat recovery from exhaust gases - } \\
\text { increase the efficiency of fuel use }\end{array}$ & Use of flue gases condensing economizers \\
\hline 4. & $\begin{array}{c}\text { Reducing the demand for primary energy } \\
\text { in the fuel to cold production }\end{array}$ & Use of free-cooling system \\
\hline 5. & $\begin{array}{c}\text { Reducing the demand for primary energy } \\
\text { in the fuel to cold production }\end{array}$ & Use of absorption chillers \\
\hline
\end{tabular}

In Table 2 are presented thermal and environmental characteristics of the fuels.

Table 2. Thermal and environmental characteristics of the fuels.

\begin{tabular}{|c|c|c|c|c|c|c|c|c|}
\hline \multicolumn{3}{|c|}{$\begin{array}{c}\text { Caloric value of fuel, WO, } \\
\qquad \mathrm{MJ} / \mathrm{kg}, \mathrm{MJ} / \mathrm{m}^{3}\end{array}$} & \multicolumn{2}{|c|}{$\begin{array}{c}\text { Quality of fuel, } \\
\text { MWh }\end{array}$} & \multicolumn{4}{|c|}{ Emission of $\mathrm{CO}_{2}, \mathrm{WE}, \mathrm{kg} \mathrm{CO}$} \\
\hline 36.2 & \multirow{2}{*}{$\mathrm{MJ} / \mathrm{m}^{3}$} & Natural gas & 0.0101 & \multirow{2}{*}{$\mathrm{MWh} / \mathrm{m}^{3}$} & \multirow{2}{*}{201.1} & \multirow{2}{*}{$\mathrm{kg} / \mathrm{MWh}$} & \multirow{2}{*}{55.86} & \multirow{2}{*}{$\mathrm{kg} / \mathrm{GJ}$} \\
\hline 35.4 & & LNG & 0.0098 & & & & & \\
\hline 25.8 & $\mathrm{MJ} / \mathrm{kg}$ & Coal & 7.1667 & MWh/GJ & 340.6 & $\mathrm{~kg} / \mathrm{MWh}$ & 94.61 & $\mathrm{~kg} / \mathrm{GJ}$ \\
\hline 41.2 & $\mathrm{MJ} / \mathrm{kg}$ & Heating oil & 11.4444 & MWh/GJ & 263.2 & $\mathrm{~kg} / \mathrm{MWh}$ & 73.11 & $\mathrm{~kg} / \mathrm{GJ}$ \\
\hline & & \begin{tabular}{|l|} 
Electricity \\
\end{tabular} & & & $\overline{1041.0}$ & $\overline{\mathrm{kg} / \mathrm{MWh}}$ & & $\mathrm{kg} / \mathrm{GJ}$ \\
\hline
\end{tabular}

The energy effect resulting from the modernization is the difference in the basic energy consumption for the states before and after the modernization calculated for both states. Calculations was made as the balance of energy demand and its carriers expressed in physical units. The calculations take into account the specificity of the analyzed energy processes, technologies and equipment. Calculated energy savings are expressed in physical units $\mathrm{kWh}, \mathrm{MWh}$, GJ for a defined annual exploitation period. Selecting the scope of the modernization was preceded by an estimate of the energy effects for individual improvements.

In general, the environmental effect is understood as reducing the amount of pollutants released into the environment as a result of the implementation of energy efficiency improvement, which are the subject of investment. Emission reductions were calculated according to equation (1) as the difference in the total $\mathrm{CO}_{2}$ emissions in the areas of audit before the modernization (the baseline emissions) $E_{1}$ and after the implementation of improvement (emissions target) $\mathrm{E}_{2}$.

$$
E=\left(E_{1}-E_{2}\right) \cdot 10^{-3}, M g / \text { year }
$$

where:

the baseline emissions $E_{1}$ and the emissions target $E_{2}$ was calculated as the sum of emissions for all energy sources for the audited areas specific to the defined balance boundaries before and after the implementation of energy efficiency improvement. 
For energy carriers emissions are calculated according to the equation (2):

$$
E_{1,2}=B_{1,2} \cdot W O \cdot W E \cdot 10^{-5}, \mathrm{~kg} / \text { year }
$$

where:

$B_{1,2}$ - the amount of fuel burned in $\mathrm{kg}$ or $\mathrm{m}^{3}$, and electricity energy in $\mathrm{kWh}$, measured on a defined balance limit, before and after the implementation of energy efficiency improvement,

$W O$ - caloric value of fuel $\mathrm{MJ} / \mathrm{kg}, \mathrm{MJ} / \mathrm{m}^{3}$ (for electricity $\mathrm{WO}=1$ ),

$W E$ - emission of $\mathrm{CO}_{2} \mathrm{~kg} / \mathrm{GJ}$, and for electricity $\mathrm{kg} / \mathrm{MWh}$, determined on the basis of the above.

Reduction of emission calculated in the analysis have been rounded up to 0.1 ton of $\mathrm{CO}_{2}$ $\left(\mathrm{Mg} \mathrm{CO}_{2}\right)$ and also it was expressed as a percentage. Factors for fuels used to calculate the data of the calorific value (WO) and $\mathrm{CO}_{2}$ emission were adopted on the basis of data published by the National Administrator of the Emission Trading Scheme (Krajowego Administratora Systemu Handlu Uprawnieniami do Emisji KOBIZE). To calculate the environmental effects from the reduction of electricity consumption the value of $\mathrm{CO}_{2}$ was determined as an average for the Polish power plants producing electricity from fossil fuels. That value was amounting $\mathrm{WE}_{1}=890 \mathrm{~kg} / \mathrm{MWh}$ and emission factor related to the consumption of electricity was amounting $\mathrm{WE}_{2}=1191 \mathrm{~kg} / \mathrm{MWh}$. The average value was amounting $\mathrm{WE}=1041 \mathrm{~kg} / \mathrm{MWh}$.

In summary of audit results for each of the analyzed variants of improvement was calculated economic indicator SPBT according to equation (3).

$$
S P B T=I / Z i, \text { years }
$$

where:

$S P B T$ - simple payback time, years,

$I-$ the amount of investment expenditure, $\mathrm{zl}$,

$Z i$ - annual savings, zł/year.

\section{Research results}

Figure 2 presents predicted to achieve values of relative energy, environmental and economic effects. The negative relative energy effect occurs when is used solution with absorption chillers. But that solution is important to increase heat consumption in order to obtain the maximum energy environmental and economic saving. But in that case need to be used all five improvements.

The reason of this situation is the possibility of simultaneous use of both solutions of cogeneration variants operating at maximum heat load. This would not be possible without the absorption chillers powered by heat from cogeneration. In addition, it is stated that through the use of the described modernization it is possible to achieve relative energy effect at the level of $20.88 \%$, which meets the requirements of financing mechanisms for energy efficiency investments. 


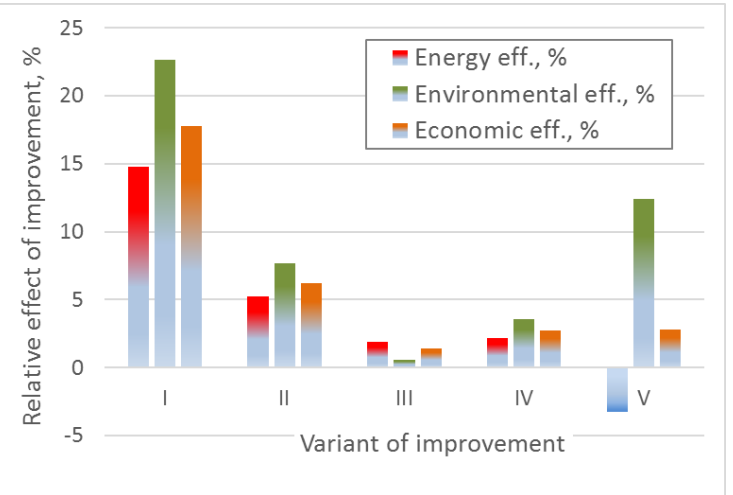

Fig. 2. Predicted to achieve values of relative energy, environmental and economic effects.

Figure 3 presents a summary of the best solutions of modernization. It can be said that the expected shortest payback time of investment was achieved for solutions with low investment cost. The most preferred solution was to use free-cooling option. Note, however, that in order to achieve raising of energy efficiency ratio above $20 \%$ is necessary to use all five variants.

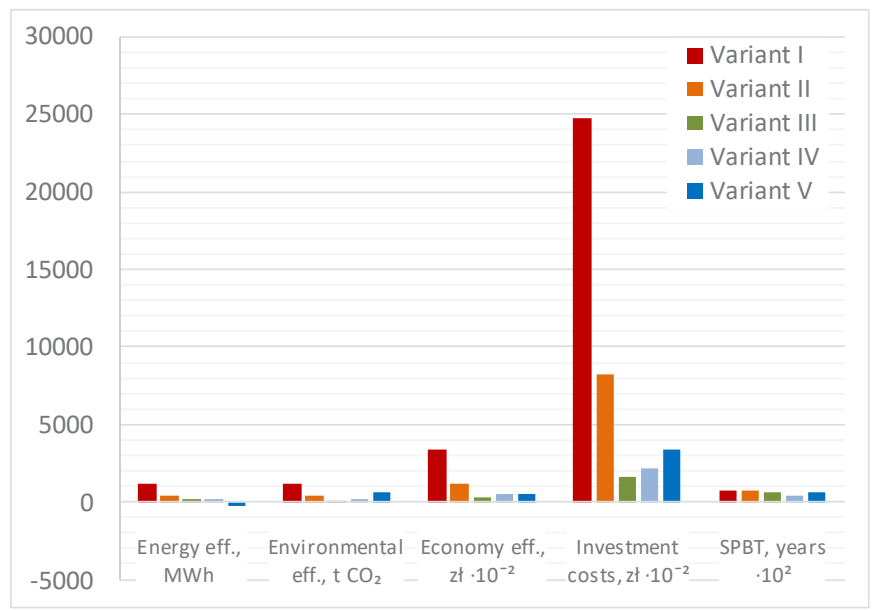

Fig. 3. Summary of the best modernization solutions.

Figure 4 presents average annual savings of final and primary energy and reduction of $\mathrm{CO}_{2}$ emission. It is found that the best solution in the terms of final and primary energy savings is the option of exchanging high-temperature hot water boiler to a cogeneration unit. 


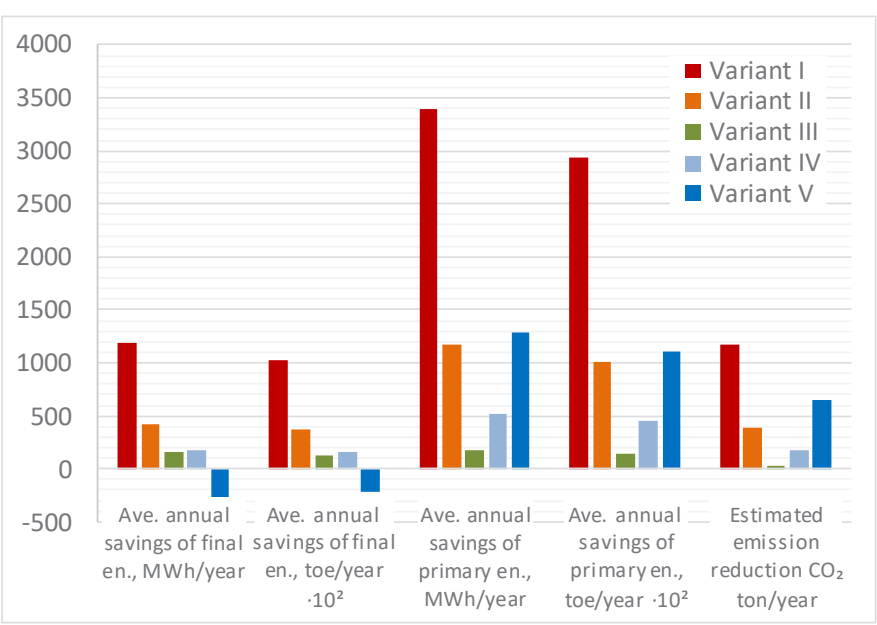

Fig. 4. Average annual savings of final and primary energy and reduction of $\mathrm{CO}_{2}$ emission.

\section{Conclusions}

Presented example represents the energy, environmental and economic situation of many businesses across the country. These companies usually invest in modern and energyefficient production lines forgetting about the modernization of installations supplying energy to the objects of the company. This results in power oversizing of heat and cold sources. However, it is extremely difficult to predict the company's production plan. Hence, sometimes it not considered to decrease the power of the equipment itself, but only increase their efficiency or use of alternative energy sources.

Therefore, first changes should be made where they can lead to significant energy, environmental and financial savings, by using relatively simple solutions that do not require significant modifications of the production cycles.

It is found that the best solution in terms of energy and environmental effect was the option of replacing the high-temperature water boiler by cogeneration module. However, the application of such a solution causes a significant investment cost.

A most advantageous economically variant was a variant involving the use of freecooling. However, only the modernization of this element will not achieve the energy efficiency ratio at a satisfactory level. Only the use of all the proposed solutions allows to achieve a rise of energy efficiency ratio by $20.88 \%$.

The relative energy effect achieved through the use of cogeneration instead of high temperature water boiler amounted to $14.78 \%$. The relative economic and environmental effects amounted respectively $17.79 \%$ and $22.62 \%$.

The relative energy effect achieved through the use of cogeneration instead of a low temperature water boiler amounted to $5.27 \%$. The relative economic and environmental effect amounted respectively $6.18 \%$ and $7.65 \%$.

The relative energy effect resulting from the use of economizers of exhaust gases amounted to $1.90 \%$, and the relative economic and environmental effects amounted respectively $1.40 \%$ and $0.60 \%$.

The relative energy effect resulting from the use of free-cooling solution amounted to $2.18 \%$, and the relative economic and environmental effects amounted respectively $2.70 \%$ and $3.53 \%$.

It is noted that the relative energy effect that can be achieved by using absorption chillers instead of compressor units is treated as a loss. Therefore, to calculation has been 
applied a negative value of relative energy effect which was $-3.25 \%$. The relative economic and environmental effects amounted respectively $2.78 \%$ and $12.44 \%$. The main idea of this solution is to allow the simultaneous use of all the proposed variants to maximize the heat load of cogeneration units.

This material has been prepared within the framework of Czestochowa University of Technology statutory research BS/PB-407-302/11 'Energy-efficient and environmentally sustainable supply systems of buildings in terms of heat, coldness and electricity'.

\section{References}

1. Directive 2012/27/eu of the European Parliament and of the Council of 25 october 2012 on energy efficiency

2. Z. Jing, X. Jiang, Q. Wu, W. Tang, B. Hua, Energy, 73:399-415 (2014)

3. Y. Li, L. Fu, S. Zhang, Y. Jiang, Z. Xiling, Energ Convers Manage, 52:1200-1207 (2011)

4. R. Sekret, Efekty środowiskowe systemów zaopatrzenia budynków w energię, (Wydawnictwo Politechniki Częstochowskiej, Częstochowa, 2012)

5. K. Nogaj, M. Turski, R. Sekret, E3S Web of Conferences 22, 00124:1-7 (2017)

6. M. Turski, R. Sekret, E3S Web of Conferences 22, 00180:1-6 (2017)

7. J. Dalenbäck, Mikrogeneracja i energetyka rozproszona: kolektory słoneczne, systemy fotowoltaiczne, kotly na biomasę (Instytut Energetyki Odnawialnej, Racibórz, 2014)

8. C. Keil, S. Plura, M. Radspieler, C. Schweigler, Appl Therm Eng, 28:2070-2076 (2008)

9. A. Bartłomiej, Nowoczesne urządzenia i systemy klimatyzacji (Medium, Warszawa, 2014)

10. M. Turski, R. Sekret, Chemical and Process Engineering 37:293-304 (2016)

11. K. Chua, S. Chou, W. Yang, J. Yan, Appl Energ, 104:87-104 (2013)

12. M. Danielak, Alternatywne systemy chłodzenia i klimatyzacji - przewodnik (Medium, Warszawa, 2014)

13. M. Gwadera, K. Kupiec, 2011, Adsorpcyjne układy chłodnicze, 5:38-39 (2011). 